\title{
A Case Study: Translation Problems in the Story of Rustam and Sohrab Based on Warner \& Warner Translation
}

\author{
Habibollah Mashhady ${ }^{1} \&$ Mahbube Noura $^{1}$ \\ ${ }^{1}$ Faculty of Letters \& Humanities, University of Zabol, Iran \\ Correspondence: Mahbube Noura, MA in Translation Studies, Faculty of Letters \& Humanities, University of \\ Zabol, Iran. E-mail: nouramahbube@yahoo.com
}

$\begin{array}{ll}\text { Received: April 17, } 2012 & \text { Accepted: May 26, } 2012 \quad \text { Online Published: July 27, } 2012 \\ \text { doi:10.5539/elt.v5n9p115 } & \text { URL: http://dx.doi.org/10.5539/elt.v5n9p115 }\end{array}$

\begin{abstract}
Throughout the history, translation has played an important role in conveying thoughts and knowledge from one nation to other nations. Apart from this importance, the act of translating is not simply changing a message from the source language into the target one; translation is an act of problem-solving. Sometimes it is difficult to solve problems existing in translation, and so the notion of untranslatability emerges. Regarding the text-types, this problem is more prominent in the translation of literary texts like poems. This study attempts to investigate untranslatable elements in a poem, and for this purpose it concentrates on the story of Rustam \& Sohrab selected from Shahnameh by Firdowsi and its equivalent translation by Warner \& Warner. Then it focuses on the relation of untranslatablility in the story of Rustam \& Sohrab with the semantic translation of Warner \& Warner and the style of Firdowsi. Further research is required in this direction to answer questions concerning the notion of untranslatability and other related matters like the purpose of translation and untranslatability.
\end{abstract}

Keywords: literary translation, the story of Rostam and Sohrab, Warner and Warner translation, untranslatibilty

\section{Introduction}

Human being is a social creature having an inclination towards interaction; one of the ways that she / he interacts is translation. In fact, through translation, they attempt to convey their thoughts and knowledge. In Bate's words, "Nothing moves without translation. No change in thought or in techniques spreads without the help of translation, because if it is to spread, it has to spread from people to people and therefore from language to language" (1936: 7). According to Newmark (1988: 7), "translation is a craft consisting in the attempt to replace a written message and / or statement in another language". So, in the process of translating, translators deal with two languages: Source language (SL) and Target language (TL). It means that translators should decode the information which is encoded in source language in respect of the structures of the two languages. Regarding the abovementioned definitions proposed for translation, is it possible to replace a message in the SL by a massage in the TL completely and without any problem? Apparently it is not so. Since no two languages are identical, surely problems arise in the process of translating. Here the notion of translatability and untranslatability emerges; these two terms are proposed to examine the extent to which a text with its all nuances including intralanguage and metalanguage factors can be rendered into another language. Some scholars in translation studies define untranslatability in terms of the original text-type, the purpose of translation, and the translation method. By reference to these factors (text-type, purpose and translation method), they reject the absolute translatability. As it was mentioned, one of the important factors in the definition of translatability is text-type. Based on Newmark, there are three types of text: 1) informative text-type in which the "topic" or content is the main focus, 2) the expressive text-type in which the author and the aesthetic dimension are important, 3) vocative text-type in which the reader-response is important. This study will concentrate on the notion of untranslatability in the expressive text- type, namely poetry. For this purpose, at first the writer examines the untranslatable elements in poems which include only literary or aesthetic factors here. Then, they are investigated in the story of Rustam and Sohrab by Firdowsi, the well-known poet of Persian language and its equivalent translation by Warner \& Warner. After comparing the Persian elements persisting to the English translation, their untranslatability will be explained in terms of translation method and the original style of writer.

\section{What Is Untranslatability?}

Translation used to be considered an inter-language transfer of meaning; talking about the faithful transfer of 
meaning from the SL to the TL, the issues of translatability and untranslatability arises and throughout the history of translation the question "Is translation possible or impossible?" has been repeatedly asked and debated among philosophers, linguists as well as translators and translation theorists. Among all kinds of text-types, there has been a considerable literature on the degree literary texts are translatable. In other words, translating literary texts, namely poetry has been the potential scene for translators, linguists and scholars to talk on untranslatability. Translation of poetry was, and still by some, believed as impossibility. The arguments include linguistic elements and cultural ones. Most importantly untranslatability looks upon poetry as beauty itself which is untouchable for once it is touched it is destroyed.

Croce (quoted in Carrveta, 1997) holds that poems cannot be composed, as each is unique. Translation is impossible; it is only a pedagogical necessity. The responsibility of the interpreter is to capture "the mood or state of being of its author."

Catford (1965) distinguishes two kinds of untranslatability, that is, linguistic untranslatability and cultural untranslatability.

Linguistic untranslatability, according to Catford, occurs when there is no lexical or syntactical substitute in the target language for a source language item. For example, the Danish Jeg fandt brevet (literally "letter [I] found the") is linguistically untranslatable, because it involves structures that does not exist in English.

Cultural untranslatability is due to the absence in the target language culture of a relevant situational feature for the source text. For example, the different concepts of the term for bathroom are untranslatable in an English, Finnish or Japanese context, where both the object and the use made of that object are not at all alike (Bassnett-McGuire, 1980: 32).

Others (Von Humboldt, Quine, Virginia Woolf, and Derrida, to name a few) insist that translation is ultimately impossible. Von Humboldt e.g. maintains that all translations are apparently attempts at finding a solution to some insoluble problem (Ke, 1991: 10).

Darbelnet and Viney (quoted in Wilss, 2001) have analyzed in detail the points of linguistic difference between the two languages, differences that constitute areas where translation is impossible. Popovic (quoted in Wilss, 2001) also has attempted to define untranslatability without making a separation between the linguistic and cultural factors.

Wolfram Wilss (quoted in Wolfram Wilss, 2001) says, "the translatability of a text can thus be measured in terms of the degree to which it can be re-contextualized in TL, taking into account all linguistic and extra-linguistic factors... The translatability of a text is thus guaranteed by the existence of universal categories in syntax, semantics, and the (natural) logic of experience.... Linguistic untranslatability occurs when the linguistic form has a function beyond that of conveying factual relationships and is therefore is a constituent part of the functional equivalence to be achieved. This, for example, is that of play on words, which can usually be adequately translated semantically but not stylistically."

Jacobson (1966: 238, quoted in Wolfram Wilss, 2001) comes to conclusion that poetry by definition is untranslatable. Only creative transposition is possible.

All scholars mentioned above directly and indirectly considered two types of untranslatability: linguistic untranslatability and cultural untranslatability. To analyze both kinds of untranslatability in the Story of Rostam and Sohrab is beyond the scope of this paper. So, it only explores untranslatability in the light of linguistic factors although both linguistic and cultural elements are interrelated.

\section{Significance and Purpose of the Study}

Although this topic is an important one in translation, no one has ever done research on it. Since this topic is a problematic one and hitherto no one has done research on the relationship between untranslatability and translation method on the one hand and its relationship with the style of original writer on the other hand it seems necessary to investigate this issue. The purpose of this study is to find the relation between untranslatable elements in the story of Rustam and Sohrab by Firdowsi, translation method exerted by Warner \& Warner and the style of original writer (Firdowsi). It is hoped that the findings of this research can be useful to translators, translation students, translation trainees and literary scholars; furthermore, consideration of untranslatability in terms of translation method can lead to modify the notion of untranslatability and also make us appreciate our literary figures, masterpieces and their uniqueness in the world. Since it is aimed to examine an English translated version of Shahnameh, namely, the story of Rustam and Sohrab, it is proper to present a précis of its history. 


\section{A Brief Summary of Shahnameh Translations}

Joseph Champion was the first one who translated Shahnameh. His book, entitled "the poems of Firdowsi" published in 1788. He translated it in verse from the birth of Rustam. Then in 1814 James Atkinson translated the story of Rustam \& Sohrab in both prose and verse. In 1832 he translated the synopsis of Shahnameh into English in nine volumes. In the early 20th century, two brothers, Arthur George and Edmund Warner translated Shahnameh into English in nine volumes. After them, Reuben Levy rendered it into English prose. Jerome Clinton is another translator of shahnameh including the story of Rustam and Sohrab. The most recent translation of Shahnameh has done by Dick Davis. He translated it into English prose and published it in 2007. In addition to these abovementioned translations, a great number of stories in Shahnameh have been adapted and translated in proses which are beyond the scope of this paper to be included.

\section{Method}

The story of Rustam \& Sohrab, from Shahnameh of Firdowsi edited by Sobhani (1383), has been selected as the literary source texts to be compared closely with their corresponding English translated text by Warner \& Warner In this research, there were some imitations, namely, time restriction which itself yielded other restrictions. Due to this restriction, only the story of Rustam and Sohrab were selected as the representative of Shahnameh. To collect data, the same texts were read and the instances containing the untranslatable elements or elements difficult to translate were identified. After that, their equivalent instances were identified and then they were compared to the Persian elements. At the last part, their untranslatability had been explained in terms of two factors: translation method and the style of writer.

\section{Literary or Aesthetic Problems}

Aesthetic values or poetic truth in a poem are conveyed in word order, and sounds, as well as in cognitive sense (logic). These aesthetic values have no independent meaning, but they are correlative with the various types of meaning in the text. Hence, if the translator destroys the word choice, word order, and the sounds, he impairs and distorts the beauty of the original poem. Delicacy and gentleness, for instance, will be ruined if the translator provides crude alliterations for the original carefully composed alliterations. So, the problems in translating a poem is how to retain the aesthetic values in the TL text. The aesthetic values, according to Newmark (1988: 651) are dependent on the structure (or poetic structure), metaphor, and sound. Poetic structure includes the plan of the original poem as a whole, the shape and the balance of individual sentences in each line. Metaphor is related to visual images created by combinations of words, which may also evoke sound, touch, smell, and tastes, while sound is anything connected with sound cultivation including rhyme, rhythm, assonance, onomatopoeia, alliteration, etc. In the following, we attempt to examine these problems in a tangible way by citing examples from the story of Rustam and Sohrab and try to assess how much they are translatable.

\subsection{Poetic Structure}

The first factor is structure. It is important to note that structure meaning here is the plan of the poem as a whole, the shape and the balance of individual sentence or of each line. So, it is not related directly to the sentential structures or grammar of a language, although it is very much affected by the sentential structure. Thus, maintaining the original structure of the poem may mean maintaining the original structure of each sentence. The following are some examples in the story of Rustam and Sohrab and its translations by Warner and Warner: did they retain the original poetic structure?

Example (a)

$$
\begin{aligned}
& \text { بر مادر آمد ببِرسيد از اوى } \\
& \text { كه من جون ز همشيركان برترم } \\
& \text { بلو كفت مادر كه بشنو سخن }
\end{aligned}
$$

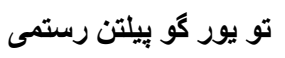

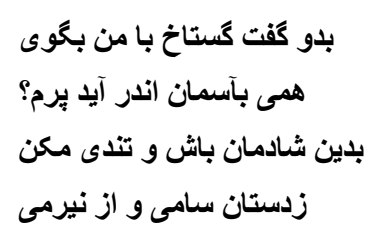

He bluntly asked his mother once: "Now tell me,

Since none of my milk - fellows can compare

With me, and my head reacheth to the sky."

His mother said: "then listen and rejoice,

But be not rash. Thou art the son of Rustam,

The hero of the elephantine from, 


\section{The progeny of Zal the son of Sam,}

\section{And Nairaman, they head out - topped heaven}

Because thou comest of the famous stock,

As you see, the poetic structure of Persian poems and its English translations is different because translations are different and translators combined two hemistiches of Persian poem into one distich like the first distich in the above example. Another reason is that they omitted some parts of distich and reduced it so that the structure of original poem has been destroyed and finally its beauty has been impaired. As a result, it can be said that the poetic structure is something untranslatable because it depends on word order, word choice and the syntactic rules of one language which themselves are language-specific and also in the case of expressive texts, these differences and gaps become more tangible. In the following, there is another example from the story of Rustam and Sohrab. Regarding the poetic structure, you can see how Warner \& Warner destroyed it through changing the sequence of original lines.
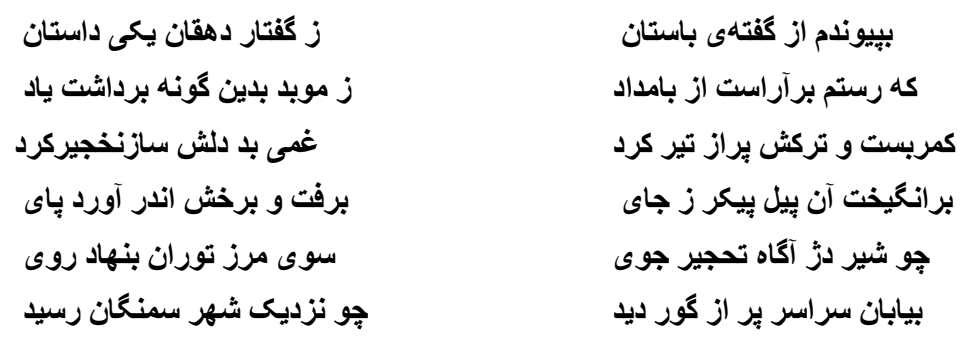

I tell what rustic bard and archimage

Told from the legends of a bygone age:

One morn in dudgeon Rustam rase to hunt,

Girt him, filled up his quiver, mounted Rakhsh,

And hied him to the marches of Turan,

A savage lion prowling after prey.

When he drew near the marches and beheld

The plain well stocked with onager,

Like the previous example, Warner \& Warner destroyed the original poetic structure. For this purpose, they omitted some parts of a line. They combined the first, the second and the third lines in a way that the narrative structure of the poem has been lost .It is more serious when they placed the fifth line immediately after the third line of original poem .Sometimes they clipped a line into one simple sentence like the forth line which has been translated into one sentence: "mounted Rakhsh". Besides of clipping a line, they accommodated it into another line; for example, the forth line has been both clipped and accommodated into another line. Regarding these examples, it becomes obvious that translating the exact poetic structure of poems especially Firdowsi's ones are not an easy task. But it challenges the process of translation from one language into another one (Persian-English).

\subsection{Metaphorical Expressions}

Metaphorical expressions, as the second factor, mean any construction evoking vision, sound, touch, and taste. They also include the traditional metaphors, direct comparisons without the words "like" and "as if", and all figurative languages. Intentionally, the writer does not use the term metaphor in sub-headings since it has different meaning for different people. What is generally known as (traditional) metaphor, for example, is not the same as metaphor meant by Newmark. To understand the meaning of metaphor as proposed by Newmark, it is advisable to understand the following terms: object, image, sense, metaphor, and metonym. Object, called also topic, is the item which is described by metaphor. Image refers to the item by which an object is described. It is also called vehicle. The next term, sense, refers to the point of similarity between aspects of the objects and the image. Metaphor here means the word(s) taken from the image. And finally, metonym refers to one-word image which replaces the object, figuratively but not metaphorically. In the expression "rooting out the faults", for example, the object is fault, the image is "rooting out weeds, the sense is (a) eliminate, (b) with tremendous effort, and the metaphor is "rooting out". The expression the "seven sea" referring to 'the whole world ' is not metaphorical. It is figurative and a metonym. Below, there are some metaphorical expressions from the story of Rustam \& Sohrab which are difficult to translate. Of course, they are untranslatable in terms of both preserving 
the same original image and the sense.

Example (a)

$$
\text { هنوز از دهن بوى شير آيلش }
$$

$$
\text { همى راه شمشير و تير آيدش }
$$

\section{Although his mouth will Savoreth have milk}

\section{His mind is set on shaft and Scimitar,}

In this example, although translators reproduced the same image in the TL, they didn't transfer the sense. Because the same sense in the two languages occurs in two different ways, the metaphorical expression for it is to smell of mother's milk. The expression "his mouth still savoureth of milk" doesn't have metaphorical meaning. Maybe scholarly reader of English language can understand its metaphorical meaning but an ordinary reader may not understand it. In conclusion, the expressive beauty of Persian poem has been impaired.

Example (b)

$$
\text { همانكُونه بخواهد ترا نزد خويش }
$$$$
\text { دل مادرت كردد از درد ريش }
$$

Then will he summon thee and rend may heart.

In the above example like the previous one, the image has been rendered. They failed to render its meaning. Again it is possible for a scholarly reader to understand its meaning by relating the image to the sense.

\section{Example (c)}

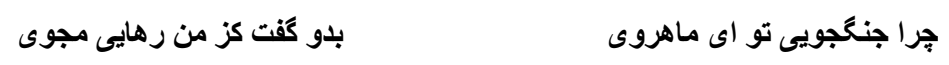

\section{Why seekest thou the fury. $O$ moon - faced maid?}

Although the word "moon" is a symbol of beauty in Persian language, it is not the same in the English; English speakers use the word "rose" to refer to beauty; therefore, the symbol of beauty is different between English and Persian. So, people translating such expressions attempt to replace them with an equivalent metaphor which moves the readers equally. As you see, it is simply possible to translate these expressions in some aspects; we mean there are not identical equivalents for them in English language. As a result, they are relative in translation; a translator cannot preserve all the elusive components of meaning peculiar to the expressive texts in the process of translation; therefore, the word "moon-faced" is not the exact equivalent of ماهروى, sine the speakers of these two languages have different attitude toward beauty. Examining more instances shows that Warner \& Warner attempted to translate in a literal way and tried to be loyal to the writer. In fact, their method is writer-oriented method; they aimed to retain the metaphorical expressions exerted by Firdowsi in composing poems.

Example (c)

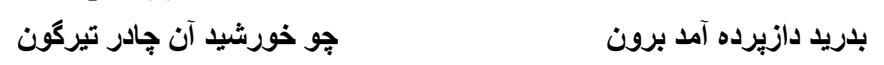

When sol had pierced night's pith- hued cloack and come

Example (d)

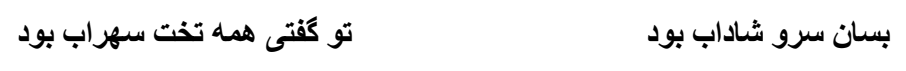

Upon the other, thou hadst said that he

\section{Filled all the throne and seemed a verdant cypress.}

It seems that Warner \& Warner had translated literally most metaphorical expressions without considering the situational context of the TL. Probably he selected this method not to confront to the problem of untranslatability.

\subsection{Sound}

The last literary or aesthetic factor is sound which is very important in composing poems, and it is an essential criterion which makes distinction between poems and other texts. It is this feature of poetry which enhances its beauty and moves the feeling of readers. In spite of the importance of sound in literary texts like poems/ poetry, it is the most difficult part of one poem to be translated. If we claim that it is not translatable at all, certainly this claim is not false. Below, there are some examples with their translations.

Example (a)

ز لثكر كزيد از دلاور سران

$$
\text { كسى كو كرايد به كَز كَران }
$$

Then from the valiant captains of the host ... 
Those that were weilders of the massive mace ...

Example (b)

$$
\text { بنزديك سهراب روشن روان }
$$

Those two shrewd paladins went to Suhrab

\section{Example (c)}

$$
\text { همى كفت از آن بس دريغا دريغ }
$$

$$
\text { كه شد ماه تابنده در زير ميخ }
$$

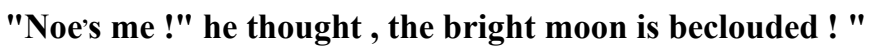

$$
\text { ز من نام بنهان نبايدت كرد }
$$

$$
\text { جوكثتى تو با كنون هم نبرد }
$$

For as my foe thou showdst not hide thy name.

\section{Art thou the famous Rustam of Zabol}

All examples presented above have a common feature, alliteration. Alliteration means the reiteration of the same sound/ sounds in a line which give a remarkable beauty to poems in terms of sound effects. Firdowsi's poems are so matchless that we can claim its uniqueness in the world. The sound helped the meaning of the poems. But maintaining this feature in another language through translation seems impossible unless the translator himself would be a poet. Through comparing the abovementioned examples with their translations, obviously every one can understand that sound effects created through alliteration has been impaired completely. Regarding these aspects of poetry, it seems possible to generalize that all poems are untranslatable. It is more serious in case of Firdowsi's poems and the story of Rustam and Sohrab because Firdowsi used sound effects widely in composing Shahnameh. From this point and regarding the translation of Warner \& Warner, Firdowsi's poems are difficult to translate.

\section{The Relation between Untranslatability, Translation Method of Warner \& Warner and the Style of Original Writer}

Before investigating the relation between untranslatability, translation method of Warner \& Warner and the style of original writer, it is appropriate to explain the translation method exerted by Warner \& Warner. Based on methods proposed by Newmark (1988), they have chosen the semantic method of translation. Newmark proposes two methods for translation: semantic and communicative translation. Newmark defines these two methods in the following way:

Semantic translation attempts to render, as closely as the semantic structures of the second language allow, the exact contextual meaning of the original. Communicative translation attempts to produce on its readers an effect as close as possible to that obtained on the readers of the original (Newmark, 1988:39).

As it was mentioned, Warner \& Warner used semantic translation, because they attempted to translate as closely as the structures of the second language regarding the syntactic rules of that language. It was more obvious in translation of metaphorical expressions. With hind sight, you can see that they rendered exact metaphorical expressions of the original poems without any modification in terms of TL context. In fact, they preferred to be loyal to the original writer and did not regard to produce on its readers an effect as close as possible to that obtained on the readers of the original. Now what is the relation between the the method of translation and untranslatability? Can translation method affect untranslatability?

Certainly there is a direct relation between them. The method of translation can determine to what extent a text like a poem is translatable and for this reason, the assumption of absolute translatability has been rejected and it is defined in relation to the original text-type, purpose of translation and the method a translator adopts for translating. Sometimes it happens that while a text is supposed to be untranslatable using an approach based on formal equivalence, it is possible to be more translatable if its apposite approach, dynamic equivalence, will be applied. As a result, some elements imposing problems in the process of translation can be rendered successfully into another language if the translator uses more various and different approaches in translation. Regarding these statements, some of the untranslatable elements mentioned in this paper based on the translation method applied by Warner \& Warner comes back to the fact that they aimed to reproduce the contextual meaning of the original text considering the cultural context of the TL; therefore, some elements rooted in the SL culture resist to this method of translation; for example, metaphorical expressions were difficult to translate because they were rooted in the Persian culture. Finally, we can conclude that semantic translation is appropriate for some features of one poem not its whole, like poetic structure. We can conclude that some untranslatable elements found in the story of Rustam and Sohrab are untranslatable due to this approach, which is semantic translation. The 
untranslatability of some elements has another reason; it is the highly qualified style of one poet in a way that if a translator attempts to translate it using all available approaches in translation ranging from word-for- word translation to free translation, it will still remain untranslatable. This is the relation of untranslatability and the style of original poet; therefore, some challenges arising in translation of one poem depend on whether its style is highly qualified or not.

Investigating the story of Rustam and Sohrab from this point, it becomes obvious that most problems of untranslatability in this story are related to the excellent and qualified style of Firdowsi and his competency in using sound effects like alliteration.

\section{Conclusion}

Throughout the history, written and spoken translations have played a crucial role in interhuman communication, not least in providing access to important texts, for scholarship religious and artistic purposes. Absolutely, all people know the importance of translation. But the act of translating is not an easy act for the translator who deals with two languages having different syntactic, semantic and pragmatic rules; therefore, translation is always a problem-solving act. Sometimes these problems seem impossible to solve. It is here that the issues of translatability and untranslatability come into play. In this paper, we attempted to investigate the notion of untranslatability and its factors including literary or aesthetic ones throughout the story of Rustam and Sohrab and its equivalent translations by Warner \& Warner. After comparing the untranslatable elements in the story of Rustam and Sohrab regarding their translation, it became obvious that they are untranslatable for two reasons: the translation method exerted by Warner \& Warner (semantic) translation, and the highly qualified style of Firdowsi. Of course, there are many other factors which influence the extent of translatability and untranslatability but they are beyond the scope of this paper. Every research is an incomplete and continuous process and demands other researchers to investigate other influential factors on the same issue.

\section{References}

Bassnett, S. (1980). Translation Studies. London \& New York: Methuen. http://dx.doi.org/10.4324/9780203427460

Bassnet, S. (1992). Translation Studies. London \& New York: Routlege.

Bate, E. S. (1936). Itertraffic: Studies in Translation. London: J. Cape.

Bell, R. T. (1991). Translation \& Translating: theory and practice. Newyork: Longman.

Catford, J. C. (1965). A Linguistic Theory of Translation. London: Oxford University Press.

Crystal, D. (1987). The Cambridge Encyclopedia of Language. Cambridge: Cambridge University Press.

Frawley, W. (1953). Translation: literary \& philosophical Perspectives. London \& Toronto: Associated university press.

Joveini, A. A. (2004). The story of Rostam \& Sohrab. Tehran: Tehran University Press.

Ke, P. (1995/1996). Yinghan yu Hanying Fanyi Jiaocheng (English-Chinese and Chinese English Translation). Taibei: Bookman.

Ke, P. (1996). A Socio-semiotic Approach to Meaning in Translation. Babel, 42(2), 74-83.

Kusha, A. (1399). The five treasures of Firdowsi. Tehran: Attelye Honar Publishers.

Munday, J. (2001). Introducing Translation Studies: Theories and Application. London: Routledge.

Newmark, P. (1988). A Textbook of Translation. London: Prentice Hall.

Newmark, P. (1989). Introductory Survey. In C. Picken (Ed.), The Translator's Handbook. London: Aslib.

Sobhani, T. H. (2005). The Shahnameh of Abolghasem Firdausi. Tehran: Rozaneh.

Warner, A. G., \& Warner, E. (1925). The Shahnama of Firdowsi. London: Keegan Paul. 